\title{
CURRICULUM CONTENT IN THE SCHOOL SUBJECT TECHNOLOGY FROM THE TEACHERS` POINT OF VIEW
}

Alena HAŠKOV $\boldsymbol{A}^{*}$, Univerzita Konštantína Filozofa v Nitre, Slovensko Silvia MANDUL'AKOVÁ, Univerzita Konštantína Filozofa v Nitre, Slovensko

Přijato: 30. 1. 2017 / Akceptováno: 24. 2. 2017

Typ článku: Teoretická studie

DOI: $10.5507 /$ jtie.2017.006

Abstract: In the period of the years 2008 - 2013 a curricular reform was introduced into the $6^{\text {th }}-9^{\text {th }}$ grades of primary schools in Slovakia. Consequently in 2013 - 2015 various aspects of the reform impact on technology education were assessed within a national project "Analysis of the curricular reform impact on technical education at lower level of secondary education". A need for a deeper analysis of some from the qualitative aspects of the research provoked into carrying further research surveys based on personal inquiries of teachers with a longer practice in teaching the school subject Technology. One of the researches was a survey research of teachers' opinions on curriculum content of this subject.

Key words: school subject Technology, ISCED 2, curricular reform.

\section{OBSAHOVÉ ZAMERANIE VÝUČBY PREDMETU TECHNIKA Z POHLADU UČITELOV}

Abstrakt: Vobdobi rokov 2008 - 2013 bola postupne na Slovensku do jednotlivých ročníkov 2. stupňa základnej školy zavedená obsahová reforma. Jednotlivé aspekty dopadu kurikulárnej reformy na technické vzdelávanie boli následne v období rokov 2013 - 2015 zhodnotené v rámci celoštátneho výskumu "Analýza dôsledkov obsahovej reformy na technické vzdelávanie na základných školách”. Potreba hlbšej analýzy niektorých kvalitativnych aspektov výskumu bola podnetom na uskutočnenie d'alšich šetrení, založených na osobných dopytovaniach učitelov s viacročnou praxou vyučovania predmetu Technika. Jedným z nich bolo zistovanie názorov učitel'ov na obsahové zameranie výučby tohto predmetu.

Klúčové slová: vyučovací predmet Technika, ISCED 2, obsahová reforma.

\footnotetext{
*Autor pro korespondenci: ahaskova@ukf.sk
} 


\section{1 Úvod}

Podl'a školského zákona SR (Zákon č. 245/2008 Z. z.) hlavnými ciel'mi výchovy a vzdelávania je umožnit' diet'at'u a žiakovi získat' kompetencie v oblasti komunikačných schopností a komunikácie $\mathrm{v}$ štátnom, materinskom a cudzom jazyku, kompetencie v oblasti využívania informačno-komunikačných technológií a matematickej gramotnosti, kompetencie v oblasti technických vied, prírodných vied a technológií ako aj kompetencie kultúrne, sociálne a občianske. Avšak ako konštatujú členovia Predmetovej komisie Človek a svet práce Štátneho pedagogického ústavu T. Kozík a D. Lukáčová (2016), $\mathrm{v}$ dôsledku spoločenských zmien dochádza k postupnej zmene chápania významu, zmyslu a užitočnosti technického vzdelávania detí na základných školách. V školskej praxi sa eliminuje priestor venovaný rozvoju praktických technických zručností, poznania vlastností materiálov a technických princípov predmetov a zariadení, s ktorými bežne prichádzame do kontaktu a v podstate ich každodenne požívame. Vyučovací predmet Technika je zatláčaný do úzadia a na základných školách je vnímaný ako predmet nepodstatný, nepotrebný až nežiaduci. Na problematické aspekty negatívneho vývoja vyučovania Techniky na základných školách je poukazované aj v príspevku A. Hašková S. Mandul'áková - D. Van Merode (2017). Jedným z týchto aspektov sú aj kurikulá predmetu Technika. Otázka je, na aké tematické celky by sa mala orientovat' výučba predmetu Technika v jednotlivých ročníkoch, aby bolo naplnené poslanie tohto predmetu. Hl'adanie odpovede na túto otázku bolo predmetom nami realizovaného výskumného šetrenia.

\section{Stratégia riešenia obsahového zamerania technického vzdelávania na školách}

Na základe nariadenia Národnej rady Slovenskej republiky mala vláda SR do konca marca 2013 spracovat' Správu o stave školstva a systémových krokoch na jeho rozvoj. Táto správa mala dat' školstvu víziu a koncepciu systémových krokov jeho d’alšieho rozvoja a dlhodobého smerovania. Vtedajší minister školstva Dušan Čaplovič (4. 4. 2012 - 3. 7. 2014), ešte predchodca bývalých ministrov Petra Pellegriniho (4. 6. 2014 - 25. 11. 2014) a Juraja Draxlera (26. 11. 2014 - 23. 3. 2016), koncept správy síce pripravil, dal ho aj na verejnú diskusiu, a po zapracovaní pripomienok verejnosti výsledný materiál v septembri 2013 predložil vláde na medzirezortné pripomienkovanie (MŠVVaŠ SR, 2013), táto správa však dodnes do programu rokovania vlády zaradená nebola. Nestalo sa tak ani napriek požiadavke signatárov Deklarácie Odborového zväzu pracovníkov školstva a vedy na Slovensku a partnerských reprezentácií pôsobiacich v školstve na podporu skvalitňovania podmienok a úrovne vzdelávania a vedy v Slovenskej republike (OZ PŠaV, 2016), ktorí ešte pred parlamentnými vol'bami, ktoré sa konali v marci 2016, vyzvali politické strany kandidujúce vo do Národnej rady SR prijat’ záväzok, že v spolupráci s partnerskými reprezentatívnymi organizáciami ešte do konca roku 2016 vypracujú a schvália Národnú stratégiu rozvoja školstva a vzdelávania, ktorá by vychádzala zo Správy o stave školstva na Slovensku a o systémových krokoch na podporu jeho d’alšieho rozvoja (MŠVVaŠ SR, 2013). Za naplnenie tejto výzvy však možno považovat' materiál s názvom Národný program rozvoja výchovy a vzdelávania Učiace sa Slovensko, ktorý dal súčasný minister školstva Peter Plavčan na verejnú diskusiu prostredníctvom webových stránok MŠVVaŠ SR v októbri 2016 (MŠVVaŠ SR, 2016). Ide o pracovný materiál, na príprave ktorého sa podiel'al expertný tím v zložení Vladimír Burjan, Milan Ftáčnik, Ivan Juráš, Peter Mederly, Matej Šiškovič, Juraj Vantuch, Emil Višňovský, Libor 
Vozár

a Zuzana Zimenová. Ministerstvo v ňom prezentuje základný rámec zmien, ktoré chce dosiahnut' v dlhodobom 10-ročnom výhl'ade v oblasti výchovy a vzdelávania. Základným ciel'om výchovy a vzdelávania podl'a tohto materiálu má byt' vyvážené naplńanie potrieb jednotlivca a spoločnosti. Na základe odbornej diskusie k zverejnenému dokumentu ministerstvo chce získat' spätnú väzbu vo forme konkrétnych podnetov k jeho obsahovému zameraniu.

Ako sa konštatuje v pripravovanom Národnom programe rozvoja výchovy a vzdelávania Učiace sa Slovensko (MŠVVaŠ SR, 2016), Slovensko zatial' dostatočne nezareagovalo na výzvy prechodu od industriálnej k informačnej spoločnosti a na to, aký je dopad nových technológií na potrebu nových zručností. Vo výrobnej sfére tradičné zručnosti, nástroje a techniky opracovávania ustupujú novým požiadavkám v podmienkach digitalizácie, automatizácie a narastajúceho významu aditívnej výroby. Toto sa však adekvátne neodráža v odbornej príprave realizovanej systémom regionálneho školstva. Odborné vzdelávanie na Slovensku je už dlhodobo predmetom ostrej kritiky. Nespokojnost' je predovšetkým s nízkou úrovňou praktického vyučovania, ktorá sa odvíja od nedostatočného a zastaraného materiálno-technického vybavenia stredných odborných škôl. V tejto súvislosti autori Národného programu akcentujú potrebu vypracovanie analýzy očakávaného dopadu informačnej spoločnosti na požadované vedomosti, zručnosti, postoje a návyky pracovnej sily relevantné v podmienkach Slovenskej republiky a na potrebu skúmania konkrétnych zručností, resp. kompetencií, ktoré sa dajú uplatnit' aj širšie vo viacerých pracovných pozíciách alebo zmenených podmienkach v blízkej budúcnosti. Ako stratégiu riešenia obsahového zamerania technického vzdelávania na školách možno považovat' vytýčenie ciel'a 3-7, prostredníctvom duálneho vzdelávania alebo uzatváraním zmlúv škôl so zamestnávatel'mi zvýšit' podiel vzdelávania v pracovnom prostredí (vytvorit' grantovú schému na podporu spolupráce školy a podniku pri vzdelávaní v pracovnom prostredí a špeciálne duálneho vzdelávania a zaviest’ inštitút firemnej školy, t.j. školy, ktorá je riadená podnikom a poskytuje praktické vyučovanie formou vzdelávania v pracovnom prostredí). V koncepcii Národného programu sa rieši len potreba prepojenosti odborného vzdelávania poskytovaného strednými odbornými školami s potrebami praxe a požiadavkami zamestnávatel'ov. Potreba podporit' prepojenost' odbornej prípravy s realizáciou technického vzdelávania na základných školách a analyzovat' prípadné potreby zmien v oblasti obsahu vzdelávania tu riešená nie je. Čiastočne to môže súvisiet' so skutočnost'ou, že ešte len pred troma rokmi (v roku 2013) bola dovedená do konca kurikulárna reforma základného školstva a autori Národného programu sa preto otázkou kurikúl nezaoberali. Na tento problém - problém neuvádzania ciel'ov v oblasti zmien v obsahu vzdelávania a to vo všeobecnej rovine, nie špecificky v súvislosti s realizáciou technického vzdelávania - pri hodnotení koncepcie Národného programu upozorn̆uje aj spoluautor predchádzajúcich školských reforiem Miron Zelina (2016). Navyše ako závažný nedostatok predloženej koncepcie označuje aj absenciu poučenia z toho, prečo podobné zámery predchádzajúcich reformných návrhov neboli uskutočnené, resp. nemali očakávaný pozitívny dopad smerom na prax. Z nášho pohl'adu ako slabú stránku spracovanej koncepcie možno označit' aj absenciu ucelenejšieho popisu súčasného stavu školstva a z nebo vyplývajúce identifikovanie najzávažnejších problémov. 
V tomto smere podstatne konkrétnejšia bola pripravovaná Správa o stave školstva na Slovensku a o systémových krokoch na podporu jeho d'alšieho rozvoja (MŠVVaŠ SR, 2013). Tá upozorňovala aj na prehlbujúce sa znižovanie záujmu mládeže o odborné vzdelávanie a prípravu sprevádzané, resp. posilňované aj znižovanou hodinovou dotáciou praktického vyučovania na základných školách. V súvislosti s obsahovou reformou (2008 - 2013) upozorňovala na skutočnost', že zavedenie školských vzdelávacích programov kreovaných na úrovni každej školy síce malo prispiet' k zvýšeniu lepšej pripravenosti žiakov na praktické uplatnenie sa v živote, vrátane posilnenia ich uplatnitel'nosti sa na trhu práce (nakol'ko mali zohl'adňovat' špecifické potreby školy definované na základe požiadaviek rodičov, návrhov a potrieb zamestnávatel'ov, ako aj samotných žiakov a d'alších zainteresovaných), v praxi však ich tvorba bola sprevádzaná viacerými problémami. V školách sa neuskutočnilo dôsledne prerozdelenie medzi štátnou a školskou úrovňou tvorby obsahu vzdelávania a školy autonómiu a vlastnú zodpovednost' využili len čiastočne. Prispelo k tomu nedostatočné materiálno-technické vybavenie škôl, nedostatok didaktických učebných materiálov, nedostatok financií, problémy so zabezpečením kvalifikovanej výučby, ako aj slabá osveta v zameraní na ozrejmovanie strategických zámerov školskej reformy a absencia cieleného vzdelávania učitel'ov zameraného na získanie zručností potrebných na vypracovanie školských vzdelávacích programov.

Ako strategický ciel' rozvoja regionálneho školstva Správa o stave školstva na Slovensku a o systémových krokoch na podporu jeho d’alšieho rozvoja uvádzala dostatočne financované a efektívne fungujúce regionálne školstvo zabezpečujúce kvalitnú výchovu a vzdelávanie, reagujúce na aktuálne i očakávané potreby praxe, dostupné pre všetky vrstvy spoločnosti. Zabezpečenie kvalitnej výchovy a vzdelávania bolo spájané s viacerými piliermi, pričom ako najdôležitejšie dva boli špecifikované kvalita učitel'ov a obsah vzdelávania.

V kontexte diskutovanej problematiky za najvýznamnejší strategický ciel' zakomponovaný do systémových krokov na podporu d’alšieho rozvoja regionálneho školstva považujeme úlohu 4-3, prijat’ opatrenia podporujúce záujem žiakov základných škôl o odborné vzdelávanie v súlade s potrebami trhu práce. Takýmto opatrením sa okrem iného malo stat' zavedenie predmetu Praktické vyučovanie, ktorého súčast'ou malo byt' aj poskytovanie poradenstva $\mathrm{v}$ oblasti profesijnej orientácie žiakov formou zážitkového vzdelávania na 2. stupni základnej školy. Ďalšími opatreniami zameranými na posilnenie prípravy žiakov základných škôl na ich následné d’alšie odborné vzdelávanie v súlade s potrebami trhu práce malo byt':

1. zavedenie predmetu Pracovné vyučovanie do Štátneho vzdelávacieho programu ISCED 2 pre všetky ročníky,

2. zakomponovanie informácií o možnostiach prípravy na budúce povolanie do obsahovej náplne predmetu Pracovné vyučovanie,

3. zabezpečenie dostatočnej informovanosti (aj elektronickou formou poradenstva) žiakov základných škôl a ich zákonných zástupcov o príprave na povolanie v stredných odborných školách a o miere uplatnitel'nosti ich absolventov na trhu práce, vrátane informácie o zamestnanosti v odbore, pre ktorý má príslušný absolvent kvalifikáciu,

4. legislatívne jednoznačné vymedzenie kompetencií Kurikulárnej rady ako odborného apolitického orgánu, ktorý sa vyjadruje k zásadným otázkam výchovy a vzdelávania. 
Pri porovnávaní oboch materiálov (Národný program, MŠVVaŠ SR, 2016; Správa o stave školstva, MŠVVaŠ SR, 2013) sa stotožňujeme s pripomienkou, ktorú smerom ku koncepcii Národného programu rozvoja výchovy a vzdelávania Učiace sa Slovensko vznáša B. Pupala (2016). Ten označuje metodologický postup predkladatel'ov Národného programu za problematický, nakol'ko (na rozdiel od tvorcov Správy o stave školstva na Slovensku a o systémových krokoch na podporu jeho d'alšieho rozvoja) predstavujú ciele vytýčené pre oblast' školstva, ale neuvádzajú konkrétne kroky, ako tieto ciele dosiahnut'. Navyše nešpecifikujú ani východiskový kontext nastavenia uvádzaných ciel'ov.

\section{Výskumné šetrenie požiadaviek na obsahové zameranie technického vzdelávania}

V období rokov 2008 - 2013 bola postupne na Slovensku do jednotlivých ročníkov 2. stupňa základnej školy zavedená obsahová reforma, ktorá sa výraznou mierou dotkla aj realizácie technického vzdelávania na školách. V dôsledku reformy došlo k zmene predmetu zameraného na rozvoj technickej gramotnosti žiakov. Pred reformou sa technická výchova žiakov uskutočňovala v rámci vyučovacieho predmetu Technická výchova. Reforma tento predmet zrušila a bol zavedený „nový“ predmet s názvom Technika. Z formálneho hl'adiska išlo len o zmenu názvu predmetu. Výrazné zmeny sa však týkali obsahového hl'adiska (redukcia rozsahu povinnej výučby predmetu, možnost' posilnit' technické vzdelávanie na škole prípadným využitím tzv. disponibilných hodín práve na výučbu Techniky, zavedenie dotvárania kurikúl predmetov zo strany učitel'ov/školy v rámci školských vzdelávacích programov). Jednotlivé aspekty dopadu kurikulárnej reformy na technické vzdelávanie boli následne v období rokov 2013 - 2015 analyzované v rámci celoštátneho výskumu Analýza dôsledkov obsahovej reformy na technické vzdelávanie na základných školách (Hašková \& Bánesz, 2015). Hlavným ciel’om realizovanej analýzy bolo zistit' pozitívne a negatívne atribúty realizácie technickej výchovy na základných školách v nadväznosti na zavedenie kurikulárnej reformy predmetu Technická výchova a zhodnotit', či zavedené zmeny nejakým spôsobom prispeli k zvýšeniu kvality technického vzdelávania žiakov. Potreba hlbšej analýzy niektorých kvalitatívnych aspektov realizovaného výskumu bola podnetom na uskutočnenie d'alších výskumných šetrení. Jedným z nich bolo výskumné šetrenie názorov učitel'ov na obsahové zameranie výučby predmetu Technika na základných školách.

\section{Ciel' a metodológia výskumu}

Výskumné šetrenie $\mathrm{v}$ rámci pedagogického a sociologického výskumu patrí medzi vel'mi často používané formy výskumu (Fraenkel \& Wallen, 1993; Jaeger, 1988). Jeho podstatou je dopytovanie sa širšej skupiny l'udí na konkrétny problém. Kladené otázky by pritom mali byt' formulované tak, aby neboli zamerané úzko špecificky, ale aby umožňovali dopytovaným vyjadrovat' svoje názory, postrehy, skúsenosti k riešenej problematike $\mathrm{v}$ jej širšom kontexte.

V našom prípade konkrétnym problémom v primárnej rovine bolo, čo, aké tematické celky by sa mali vyučovat' $\mathrm{v}$ rámci predmetu Technika, aby bolo naplnené jeho poslanie a aby nebola $\mathrm{v}$ praxi potláčaná jeho zmysluplnost', významnost' ako aj prínos pre formovanie profesijnej orientácie žiakov (Pavelka, 2016; Avsek \& Jamsec, 2016; Fujikawa \& Maesako, 2015) . V sekundárnej rovine riešeným problémom bolo, ako k naplneniu tohto poslania prispela obsahová reforma. Vyriešit' (aspoň čiastočne) tento problém znamenalo: 
1. identifikovat' redundantné témy (problematiky) vyučované v rámci predmetu Technika,

2. identifikovat' relevantné témy, ktoré prispievajú k naplneniu jeho poslania, t.j. potvrdit' obsahové zameranie predmetu,

3. zhodnotit' dopad reformy na vyučovanie predmetu Technika, t.j. na jeho obsahovú náplň a formy realizácie.

Vzhl'adom na skutočnost', že výskumné šetrenie bolo realizované so zámerom hlbšej kvalitatívnej analýzy predmetnej problematiky (Bogdan \& Biklen, 1992), ako výskumná metóda bola zvolená metóda osobných rozhovorov (Seidman, 1991).

Ciel'ovou skupinou dopytovania boli učitelia predmetu Technika. Požiadavkou bolo, aby to boli učitelia s dlhšou dobou praxe, aby sa mohli objektívne, na základe vlastných profesijných skúseností, vyjadrovat' k obsahovej náplni a spôsobu realizácie predmetu Technika pred a po reforme (resp. vzhl'adom na situáciu pred obsahovou reformou predmetu Technická výchova).

Nakol'ko výsledky sledovania postavenia výučby predmetu Technika na základných školách poukazujú na významné rozdiely medzi jednotlivými regiónmi (Manduláková, 2016), bolo potrebné, aby medzi dopytovanými boli zastúpení učitelia z každého regiónu. Vzhl'adom na náročnost' realizácie dopytovania formou osobných rozhovorov tu vznikol problém zostavenia výskumnej vzorky dopytovaných učitel'ov, aby táto vzorka bola reprezentatívna vzhl'adom na celé Slovensko a súčasne aby bolo pre výskumný tím reálne uskutočnit' rozhovory so všetkými. Výsledným riešením bola realizácia osobných dopytovaní so skupinami učitel'ov $\mathrm{z}$ troch krajov, konkrétne Bratislavského (BA), Banskobystrického (BB) a Prešovského (PO), ako reprezentantov západného, stredného a východného Slovenska. Charakteristika výskumnej vzorky je prezentovaná v tab. 1.

\begin{tabular}{ccccc}
\hline & $\begin{array}{c}\text { Bratislavský } \\
\text { kraj }\end{array}$ & $\begin{array}{c}\text { Banskobystrický } \\
\text { kraj }\end{array}$ & $\begin{array}{c}\text { Prešovský } \\
\text { kraj }\end{array}$ & Spolu \\
\hline Počet učitelov & 26 & 20 & 24 & 70 \\
- z toho muži & 9 & 4 & 8 & 21 \\
- z toho ženy & 17 & 16 & 16 & 49 \\
Prax > 10 rokov & 5 & 4 & 2 & 11 \\
Prax > 20 rokov & 21 & 16 & 22 & 59 \\
\hline
\end{tabular}

Tab. č.1: Počty dopytovaných učitel'ov v jednotlivých krajoch.

Ako vyplýva $\mathrm{z}$ tab. 1, celkovo bolo realizovaných 70 semištruktúrovaných rozhovorov, $\mathrm{v}$ rámci ktorých učitelia prezentovali svoje názory na:

- $\quad$ zmeny, ktoré spôsobila obsahová reforma v realizácii technickej výchovy na ich škole (t.j. vyučovanie predmetu Technická výchova pred reformou verzus po reforme vyučovanie predmetu Technika);

- ideálny stav výučby predmetu Technika (čo by považovali za ,ideálny stav“);

- d'alšie potrebné zmeny (čo v nadväznosti na kurikulárnu reformu v súvislosti s výučbou predmetu Technika považujú za potrebné d'alšie zmeny), eventuálne čo považujú za d’alšie prospešné zmeny v záujme skvalitnenia výučby Techniky;

- obsahové zameranie kurikúl predmetu Technika. 
Záznamy z rozhovorov boli následne podrobené kvalitatívnej analýze založenej na sledovaní výskytu relevantných obsahových jednotiek a kategórií a intenzite ich zdôrazňovania.

\section{Výsledky výskumu a ich diskusia}

Výsledky výskumu boli spracované zvlášt' pre každú skupinu dopytovaných (t.j. pre skupiny učitel'ov podl'a samosprávneho kraja ich pôsobenia).

\section{Závery dopytovania realizovaného $v$ Bratislavskom kraji}

Učitelia v Bratislavskom kraji sa zhodujú v názore, že kurikulá vyučovacieho predmetu Technika by t’ažiskovo mali byt' zamerané na tematiku technických materiálov a ich obrábania. Zdôvodňujú to tým, že tieto poznatky sú neoddelitel’nou súčastou všeobecného technického vzdelania. Vel'ké výhrady majú k nerešpektovaniu medzipredmetových vzt’ahov, ku ktorému dochádza jednak pri tvorbe Štátnych vzdelávacích programov ale aj pri koncipovaní školských vzdelávacích programov. Vel'mi často uvádzaným príkladom tejto skutočnosti bolo zaradenie tematického celku Elektrotechnika do vzdelávacích programov (rozdiel dvoch ročníkov: $\mathrm{v}$ rámci predmetu Technika je tento tematický celok zarad’ovaný do 6 . ročníka a v rámci predmetu fyzika do 9. ročníka). V podstate učitelia považujú celkovo výučbu elektrotechniky pre vekovú kategóriu žiakov základnej školy za vel’mi náročnú. Tematické celky zamerané na finančnú gramotnost' navrhujú presunút' do matematiky a výučbu zameranú na prácu s výpočtovou technikou a rozvoj počítačovej gramotnosti navrhujú presunút do informatiky. Kvôli zabezpečeniu kvalitného technického vzdelania mládeže považujú za dôležité, aby sa $\mathrm{k}$ problematike zamerania obsahu výučby predmetu Technika na základných školách vyjadrovali aj učitelia stredných škôl.

Všeobecný konsenzus medzi dopytovanými bol aj vo vyjadreniach týkajúcich sa foriem výučby predmetu Technika. Učitelia vo svojich výpovediach zhodne uvádzali, že obsah predmetu je náročný na prípravu a materiálne vybavenie, ale súčasne deklarovali aj svoje presvedčenie (resp. požiadavku), že každá téma by mala byt' odučená aj v praktickej forme a výučba náročnejších tematických celkov by mala byt' sprevádzaná exkurziami.

Zaujímavým výsledkom realizovaného dopytovania bolo zistenie, že v rámci diskusie ideálneho stavu výučby predmetu Technika učitelia vôbec neriešili otázku obsahového zamerania výučby predmetu. Čo riešili, bolo práve zabezpečenie praktickej formy výučby Techniky. Nedomnievame sa, že to svedčí o spokojnosti učitel'ov s učebnými osnovami predmetu. V konečnom dôsledku, určitú mieru nepokojnosti potvrdzujú vyššie uvádzané komentáre a pripomienky učitel’ov $\mathrm{k}$ vzdelávacím programom. Svedčí to však o nedostatočnej vybavenosti škôl $\mathrm{k}$ tomu, aby sa výučba Techniky mohla dominantne realizovat' na základe praktických činností, $\mathrm{v}$ dôsledku čoho $\mathrm{v}$ praxi dochádza $\mathrm{k}$ deformácii poslania tohto predmetu. Výsledkom tohto stavu bolo, že učitelia, ked' boli vyzvaní predstavit svoju víziu ideálneho stavu výučby Techniky, prioritne riešili otázku vytvorenia ideálnych podmienok pre zabezpečenie praktickej výučby - otázku vytvorenia náležitých priestorových a materiálno-technických podmienok pre výučbu predmetu, otázku efektívneho modelu financovania materiálov potrebných na praktickú výučbu jednotlivých tematických celkov a otázku zvýšenia všeobecne vel’mi nízkej akceptácie predmetu 
(v rámci vyučovacích predmetov podceňovaná pozícia Techniky, nestabilná pozícia predmetu v Štátnom vzdelávacom programe, podceňovanie významu a dôležitosti predmetu zo strany rodičov žiakov).

Pri hodnotení obsahovej reformy učitelia vel’mi často vyslovovali názor, že bola nepripravená. $Z$ ich pohl'adu sa reforma mala začat' vytvorením náležitých podmienok na jej realizáciu. K týmto podmienkam radia predovšetkým vybavenie priestorov pre výučbu Techniky a zabezpečenie učebného materiálu (zhoda s ich víziou ideálneho stavu výučby predmetu Technika). Následne sa mala realizovat' príprava učitel'ov a až potom mali byt' do výučby zavádzané obsahové zmeny. V súvislosti s prípravou učitel'ov sa kriticky vyjadrovali aj k oboznamovaniu učitel’ov so zámermi, ktoré sa mali reformou sledovat'. Nebol ojedinelý názor, že mnohí učitelia doteraz nepochopili hlavný zámer reformy. Zaujímavé názory odzneli aj v súvislosti s hodnotením súčasného stavu realizácie výučby predmetu Technika. Za takéto považujeme vyjadrenia, v ktorých učitelia označovali proces výučby Techniky (celkovo, nielen v súvislosti so školami na ktorých pôsobia) za nestabilizovaný. Opätovné zvýšenie počtu povinnej výučby predmetu Technika (Inovovaný Štátny vzdelávací program platný od 1. septembra 2015; ŠPÚ, 2015) učitelia síce hodnotia kladne, upozorňujú však na skutočnost', že pokial' sa na školách nezlepšia priestorové a materiálno-technické podmienky zabezpečenia jeho výučby, nemožno očakávat' adekvátnu kvalitu jeho výučby (bez ohl'adu na rozsah časovej dotácie predmetu a tematické zameranie jeho kurikúl) a teda ani náležitú kvalitu technických zručností žiakov. Učitelia by uvítali, keby ministerstvo zavádzanie zmien realizovalo na základe užšej komunikácie a spolupráce so školami.

Ak niektorí z dopytovaných zmieňovali vôbec nejaké pozitíva reformy, tak to súviselo to s realizáciou národného projektu Podpora profesijnej orientácie žiakov základnej školy na odborné vzdelávanie a prípravu prostrednictvom rozvoja polytechnickej výchovy zameranej na rozvoj pracovných zručností a práca s talentami (tzv. projekt Dielne; ŠIOV, 2013). Učitelia realizáciu tohto projektu vnímali ako aktivitu zameranú na podporu reformy, v skutočnosti však projekt súčast’ou školskej reformy, ktorá sa začala v roku 2008, vôbec nebol. Projekt Dielne sa začal realizovat' v roku 2013 a súvisel s programovým vyhlásením vlády z mája 2012. Schválením projektu Dielne vláda reagovala na silnejúcu kritiku odborného vzdelávania a prípravy zo strany zamestnávatel’ov a na alarmujúcu situáciu týkajúcu sa rozhodovania žiakov základných škôl o ich budúcej kariére a výbere povolania. Realizácia projektu mala prispiet' k zvýšeniu záujmu žiakov o odborné vzdelávanie. Na základe polytechnickej výchovy mali byt' žiaci vedení $\mathrm{k}$ tomu, aby pri rozhodovaní o svojom budúcom pracovnom uplatnení dôsledne zvažovali kam pôjdu študovat' a toto svoje rozhodnutie dávali do vzt'ahu k uplatnitel'nosti na trhu práce ako aj k potrebám nášho hospodárstva. Napriek tomu, že národný projekt nebol súčastou školskej reformy, nesporne mal výrazný pozitívny dopad na výučbu Techniky na školách.

\section{Závery dopytovania realizovaného $v$ Banskobystrickom kraji}

Učitelia v Banskobystrickom kraji, podobne ako učitelia v Bratislavskom kraji, pozitívne hodnotili zaradenie tematických celkov zameraných na technické materiály do vzdelávacieho programu a výhrady mali k tematickému celku Elektrotechnika. Najväčšie výhrady boli voči zaradeniu problematiky logických obvodov. Túto tému učitelia navrhujú zo vzdelávacieho programu vylúčit'. Vzhl’adom na medzipredmetové vzt’ahy Techniky 
s fyzikou upozorňovali na neprepojenost' a zbytočnost' niektorých tém a takisto ako v prípade Elektrotechniky aj na ich náročnost’ pre žiakov.

Paradoxným zistením je, že podla názoru učitel’ov nie sú potrebné d’alšie zásadné zmeny, pričom vykonané zmeny považujú za nekoordinované, bez rešpektovania názoru učitel'ov. Pri svojich prípravách na vyučovanie mnoho podnetov preberajú z Českej republiky. Ak sa majú robit' nejaké zmeny, za prospešné a efektívne považujú nie podporit' zmenu obsahu vzdelávania ale podporit obsah vzdelávania spolu s materiálno-technickým vybavením škôl.

Zhoda s výsledkami dopytovania v Bratislavskom kraji je aj v otázke ideálneho stavu vyučovania predmetu Technika. Učitelia v Banskobystrickom kraji vo svojich vyjadreniach $\mathrm{k}$ tejto otázke tiež prioritne deklarovali potrebu zabezpečenia náležitých podmienok, aby t’ažisko výučby predmetu bolo na praktických činnostiach žiakov a nie na teoretickej výučbe. Na rozdiel od Bratislavského kraja učitelia v Banskobystrickom kraji:

- $\quad$ v rámci praktických činností žiakov špecificky akcentovali potrebu rozvíjania manuálnych zručností žiakov,

- $\quad$ výraznejšou mierou deklarovali potrebu zabezpečenia metodickej podpory pre učitel'ov,

- požiadavku stabilizácie postavenia predmetu spájali s konkrétnou požiadavkou zaradenia povinnej výučby Techniky do ročníkov $6 .-9$. s časovou dotáciou 2 vyučovacích hodín týždenne,

za súčast' ideálneho stavu vyučovania predmetu považujú aj vypracovanie učebníc pre jednotlivé ročníky (a nie jednu, určenú pre všetky ročníky, ako je tomu v súčasnosti).

Pri hodnotení dopadu obsahovej reformy na realizáciu technickej výchovy na školách ani pozornost' učitel'ov Banskobystrického kraja nebola sústred’ovaná na kurikulárne aspekty reformy, ale učitelia sa spontánne dominantne vyjadrovali k podmienkam výučby Techniky. Poukazovali na skutočnost', že v dôsledku reformy sa podmienky markantne zhoršili, nakol'ko reformou (resp. Štátnym vzdelávacím programom z roku 2008; ŠPÚ, 2008) zavedené zníženie minimálneho povinného rozsahu predmetu Technika viedlo, spolu s ekonomickými dôvodmi, riaditel’ov mnohých základných škôl k rozhodnutiu zrušit' jestvujúce vybudované dielne a ich priestory využit' na iné účely. Vyskytli sa síce aj prípady, kedy učitelia deklarovali spokojnost' s podmienkami výučby predmetu, ale zakaždým to boli učitelia pôsobiaci na školách zapojených do projektu Dielne (t.j. prípady škôl, kde v rámci realizácie tohto projektu v rokoch 2013 - 2015 za účelom rozvíjania pracovných zručností žiakov boli zriadené a materiálne vybavené integrované odborné učebne pre výučbu chémie, fyziky, biológie a techniky.

Obsahová analýza vyjadrení učitel'ov v zameraní na sledovanie obsahovej jednotky priestorových a materiálnych podmienok zabezpečenia výučby predmetu Technika poukázala na dva aspekty spojené s touto jednotkou. Nedostatočné (ev. absentujúce) zabezpečenie náležitých priestorových a materiálno-technických podmienok pre výučbu predmetu Technika síce st’ažuje prácu učitel'ov a logicky znižuje kvalitu školou žiakom poskytovaného technického vzdelania ale nemožno ho označovat' za dôvod nízkeho statusu predmetu. Nízku akceptáciu významu predmetu učitelia spájajú s neustálym „pohadzovaním“ predmetu v rámci sústavy všeobecno-vzdelávacích predmetov, spochybňovaním potreby tohto predmetu ako povinného na základných školách a s tým súvisiacou nízkou spoločenskou podporou tohto predmetu. V mnohých prípadoch učitelia 
upozorňujú na skutočnost', že toto vnímanie postavenia predmetu sa odzrkadl'uje následne v postojoch a najmä rozhodnutiach vedení škôl (resp. ich výraznou mierou ovplyvňuje). Polovica dopytovaných učitel'ov v Banskobystrickom kraji spojila pozíciu predmetu priamo s vedením školy.

Z hl'adiska akceptácie predmetu a jeho spoločenského vnímania učitelia jednoznačne považovali za priaznivejší stav pred reformou.

\section{Závery dopytovania realizovaného v Prešovskom kraji}

I ked' už výsledky dopytovania realizovaného v Banskobystrickom kraji priniesli určité rozdiely v porovnaní s výsledkami získanými pre Bratislavský kraj, v Prešovskom kraji špecifickost' výsledkov v závislosti od kraja bola ešte výraznejšia.

Výsledky dopytovania v Prešovskom kraji, podobne ako výsledky v Bratislavskom a Banskobystrickom kraji, potvrdili kontroverzné zaradenie témy Elektrotechnika do kurikúl predmetu Technika. Špecifikom tohto kraja bola silná požiadavka dopytovaných zamerat' obsah predmetu na rozvíjanie praktických činností v oblasti tradičných remesiel. V súčasnosti vyučované tematické celky považujú jednak za nelogicky usporiadané a jednak za vel'mi náročné pre deti v danom veku (najmä práve vyššie uvádzanú Elektrotechniku - v súvislosti s ňou sa vo všetkých sledovaných krajoch popri požiadavke vylúčenia tejto témy z učebných osnov Techniky vyskytovali aj alternatívne návrhy na jej presun do predmetu fyzika). Žiaci pri náročných témach majú pocit neúspechu a podl’a názorov učitel'ov Techniky tento predmet by mal byt' hlavne o zážitkoch. Prácu so žiakmi na hodinách Techniky považujú učitelia za náročnejšiu ako v iných predmetoch. Vzhl'adom k témam, ktoré si vyžadujú praktické činnosti, je priebeh vyučovacej hodiny časovo, materiálne a metodicky t'ažší. Navrhujú preto učit' v malých skupinách. Ďalším špecifikom Prešovského kraja bolo, že súčasne s požiadavkou delenia tried na menšie skupiny tu zarezonovala požiadavka rozdelit', resp. zaviest' aj témy výučby zvlášt' pre dievčatá a zvlášt’ pre chlapcov. Úplne prirodzene aj v tomto kraji rezonovala požiadavka podporit' jednotlivé témy náležitým materiálnym vybavením.

Ideálny stav výučby predmetu bol aj v tomto kraji spájaný so zabezpečením „,ideálnych“ podmienok pre jeho výučbu - s modernizáciou priestorov škôl, vybavením škôl adekvátnymi materiálno-didaktickými pomôckami, zriad’ovaním skladov na materiál popri dielňach, zriad'ovaním tried vybavených výpočtovou technikou, poskytovaním náležitých metodických materiálov a školení (možností d'alšieho vzdelávania) pre učitel'ov, so zvýšením časovej dotácie povinnej výučby predmetu (v mnohých prípadoch boli 2 hodiny týždenne uvádzané ako ideálny stav).

Je otázne, do akej miery boli objektívne pripomienky $\mathrm{k}$,spravodlivému a celoplošnému“ rozdel’ovaniu projektov pre školy uvádzané pri popisoch ideálneho stavu realizácie výučby Techniky. Predpokladáme, že sa tu prejavili subjektívne pocity dopytovaných, že ich kraj je v porovnaní s inými krajmi, resp. v porovnaní s Bratislavským krajom „diskriminovaný“ (dopytovaní neboli informovaní o výbere krajov, v rámci ktorých boli realizované výskumné šetrenia, t.j. jedná sa o všeobecný pocit dopytovaných, nie o pocit evokovaný uvedením tejto informácie).

Kým dopytovaní v Bratislavskom a Banskobystrickom kraji vo všeobecnosti hodnotili dopad kurikulárnej reformy na realizáciu technického vzdelávania na školách negatívne, učitelia z Prešovského kraja vnímali tento stav v podstate ako nezmenený. Na tomto mieste treba ale upozornit', že „nezmenený“ znamená, že z pohl'adu učitel'ov reforma nepriniesla 
žiadne zásadné (či už pozitívne alebo negatívne) zmeny a „všetko ide ako pred tým“. Pritom „všetko ide ako pred tým“, znamená, pokračovanie v negatívnom vývoji realizácie technickej výchovy na školách, ktorý reforma nedokázala zastavit', nieto ešte zvrátit' (t.j. reforma nezastavila zhoršovanie podmienok výučby a tie sa postupne d’alej zhoršujú, tak ako sa postupne zhoršovali už aj pred reformou). V tejto súvislosti dopytovaní vyjadrovali svoje obavy o d'alší vývoj pozície predmetu ako aj technického vzdelávania na školách, ktoré vo vel'kej miere považujú za nezladené s trhom práce. Na druhú stranu kladne hodnotia aspoň snahu niečo zlepšit', napr. inovovanie Štátneho vzdelávacieho programu k 1. septembru 2015 (ŠPÚ, 2015).

\section{Záver}

Ako vyplýva z prezentovaných výsledkov výskumného šetrenia názorov učitel'ov na obsahové zameranie výučby predmetu Technika, z pohl'adu učitel'ov prioritným problémom nie je inovovanie či modifikovanie súčasných kurikúl, ale zmena zamerania charakteru výučby tohto predmetu. Napriek regionálnym rozdielom v získaných výsledkoch realizovaného šetrenia, spoločnou požiadavkou učitel'ov pôsobiacich na školách v jednotlivých (rôznych) regiónoch je prehĺbit' praktických charakter výučby Techniky a zamerat' sa viac na rozvoj praktických zručností žiakov pred preferovaním rozvoja ich teoretických poznatkov. Zabezpečenie tejto zmeny v realizácii technickej výchovy na školách je však podmienené vytvorením adekvátnych podmienok pre praktické činnosti žiakov. Riešenie tohto problému by však rozhodne nemalo ostat' výlučne na pleciach samotných škôl.

\section{Literatúra}

Avsec, S., \& Jamsec, J. (2016). Technological Literacy for Students Aged 6 - 18: a New Method for Holistic Measuring fo Knowledge, Capabilities, Critical Thinking and Decision-Making. International Journal of Technology and Design Edication, Vol. 26, No. 1, s. 43 - 60. ISSN: 0957-7572 (print version), 1573-1804 (electronic version).

Bogdan, R. C., \& Biklen, S. K. (1992). Qualitative Research in Education. 2. vyd. Boston : Allyn \& Bacon, 1992.

Fraenkel. J. R., \& Wallen, N. E. (1993). How to Design and Evaluate Research in Education. 2. vyd. USA : McGraw-Hill, Inc., 1993. ISBN 0-07-021771-8.

Fujikawa, S., \& Maesako, T. (2015). Present Situation and Prob lems of Technology Education in Japan: With Focusing on Technology Education as General Education. International Research in Education, Vol. 3, No. 2, s. 173 - 182. ISSN 2327-5499.

Hašková, A., \& Bánesz, G. (2015). Technika na základných školách - áno alebo nie. Praha : Verbum, 2015. ISBN 978-80-87800-31-7.

Hašková, A., Manduláková, S., \& Van Merode, D. (2017). Problematic Aspects of Technology Education in Slovakia. Communications: Scientific Letters of the University of Žilina, Vol. 19, No. 1/2017, s. 75 - 80, ISSN 1335-4205.

Jaeger, R. M. (1988). Survey Research Methods in Education. R. M. Jaeger (Ed.): Complementary Methods for Research in Education. Washington, DC: American Educational Research Association, 1988.

Kozík, T., \& Lukáčová, D. (2016). Innovation of Technical Education in the Slovak Republic - a Challenge for Teachers, Pupils and Parents. Jounal of Technology and 
Information Education, Vol. 7, No. 2/2016, s. 42 - 52, ISSN 1803-537X (print), 18036805 (on-line).

Manduláková, S. (2016). Regionálne rozdiely vo vyučovaní predmetu Technika. Vzájomná informovanost' - cesta $k$ efektívnemu rozvoju vedecko-pedagogickej činnosti, Nitra : PF UKF, 2016, s. 32 - 39, ISBN 978-80-558-1094-2.

MŠVVaŠ SR (2016). Národný program rozvoja výchovy a vzdelávania Učiace sa Slovensko. Dostupné z: http://www.minedu.sk/tezy-k-narodnemu-programu-rozvojavychovy-a-vzdelavania.

MŠVVaŠ SR (2013). Správa o stave školstva na Slovensku a o systémových krokoch na podporu jeho d’alšieho rozvoja. Dostupné z: file:///G:/Subory\%20od\%2006-052015/Publ/JTIE/Podklady/Správa\%20o\%20stave\%20školstva\%202013.pdf.

OZ PŠaV (2016). Deklarácia Odborového zväzu pracovnikov školstva a vedy na Slovensku a partnerských reprezentácii pôsobiacich $v$ školstve na podporu skvalitňovania podmienok $a$ úrovne vzdelávania a vedy $v S R$. Dostupné z: http://www.ozpsav.sk/sk/Aktuality/udalosti-oznamy/deklaracia-odboroveho-zvazupracovnikov-skolstva-a-vedy-na-slovensku-a-partnerskych-reprezentac.alej.

Pavelka, J. (2016). Developing Students'Select Competences during Technology, Physics and Mathematics Lessons at Basic Schools. Jounal of Technology and Information Education, Vol. 7, No. 2/2016, s. 76 - 92, ISSN 1803-537X (print), 1803-6805 (on-line). Pupala, B. (2016). Riedky sen o „Učiacom sa Slovensku“. Dostupné z: https://www.postoj.sk/18134/riedky-sen-o-uciacom-sa-slovensku.

Seidman, I. E. (1991). Interviewing in Qualitative Research. New York : Teachers College Press, 1991.

ŠIOV (2013). Národný projekt Podpora profesijnej orientácie žiakov základnej školy na odborné vzdelávanie a pripravu prostredníctvom rozvoja polytechnickej výchovy zameranej na rozvoj pracovných zručností a práca s talentami, projekt č. 26110130549, 2013. Dostupné z: http://www.zsodborne.sk/index.php/o-projekte/o-projekte.

ŠPÚ (2008). Štátny vzdelávaci program. Dostupné z: http://www.statpedu.sk/clanky/statny-vzdelavaci-program

ŠPÚ (2015). Inovovaný Śtátny vzdelávaci program. Dostupné z: http://www.statpedu.sk/clanky/inovovany-statny-vzdelavaci-program

Zákon č. 245/2008 Z. z. o výchove a vzdelávaní (školský zákon) a o zmene a doplnení niektorých zákonov $v$ zneni neskoršich predpisov. Dostupné z: https://www.slovlex.sk/pravne-predpisy/SK/ZZ/2008/245/20160901.

Zelina, M. (2016). Tvrdá kritika chystanej reformy školstva na Slovensku: Experti objavujú objavené! Dostupné z: http://www.pluska.sk/rady-tipy/10/dalsia-reforma-skolstva-vazeniste-si-isti-teraz-nase-deti-neprepadnu-sutazi-so-zahranicim.html. 